\title{
EFFECT OF SULPHUR AND RICE STRAW COMPOST ON SOME SOIL PROPERTIES, SOYBEAN YIELD AND ITS NUTRIENT CONTENTS
}

Talha N. I. A. ; I. E. Nasr EL-Din ; B. A. Zamil and A. S. M. EL-Saady

Soils, Water and Environment Res. Inst., Agric. Res. Center, Egypt.

\begin{abstract}
A field experiment was conducted during two successive summer seasons of 2010 and 2011 at the experimental farm of Sakha Agric. Res. Station, Kafr EL-Sheikh Governorate. This study was conducted to investigate the effects of N-mineral and organic fertilizers (rice straw compost) with or without sulphur on soybean yield, its chemical composition and soil contents of $\mathrm{N}, \mathrm{P}$ and $\mathrm{K}$. The experiments were conducted in split plot design, where the main plots were allotted for soybean cultivars; Crowford $\left(\mathrm{Cv}_{1}\right)$, Giza111 $\left(\mathrm{Cv}_{2}\right)$, and Taiwan $\left(\mathrm{Cv}_{3}\right)$. The sub plots were allotted for fertilizer treatments: $1-\mathrm{N}$ fertilizer as urea at level of $15 \mathrm{~kg}^{\text {. Nfed }}{ }^{-1}$ (control treatment) 2-Rice straw compost at rate of 10 tonfed $^{-1}$ (OM), 3 -Rice straw compost at rate of 10 tonfed $^{-1}+$ sulphur at rate of $400 \mathrm{kgfed}^{-1}(\mathrm{OM}+\mathrm{S}), 4-\mathrm{N}$ fertilizers as urea at rate of $15 \mathrm{~kg} \mathrm{~N}$ fed $^{-1}+$ sulphur of $400 \mathrm{kgfed}^{-1}(\mathrm{~N}+\mathrm{S})$. The treatments were replicated four times.

The results can be summarized as follows:-

1 - The yield and its components of soybean were significantly affected by fertilizers treatments and soybean cultivars

2- The highest soybean biomass and seed yields were obtained by $\mathrm{Cv}_{1}$ under $\mathrm{OM}+\mathrm{S}$ treatment

3- The maximum values of $\mathrm{N}, \mathrm{P}$ and $\mathrm{K}$ contents in the seeds were obtained by $\mathrm{Cv}_{1}$ under OM treatment

4- The highest $\mathrm{N}$ and $\mathrm{P}$ content in straw were recorded by the control treatment, where the highest values of $\mathrm{K}$ content were obtained by $\mathrm{OM}+\mathrm{S}$ treatment

5- $\mathrm{N}+\mathrm{S}$ treatment had the highest protein content in the seeds.

6- OM treatment recorded the highest values of available N, P and $\mathrm{K}$ in soil
\end{abstract}

\section{INTRODUCTION}

Soybean (Glycine Max L.) as healthy food. It is a cheep source of oil and protein. Sulphur considered of special importance for leguminous plants due to its essentiality in amino and nucleic acids formation and protein metabolism (Mohamed et al 2001). Sulphur reduce soil pH resulting in higher nutrient availability and better physical conditions(Agrisnet :manures2011). It is well known that soils of arid and semi-arid regions are poor in organic matter, so maintenance of soil organic matter is a partial problem of soil fertility in Egypt . Organic materials such as crop residues (rice straw) are available in abundance and reach tremendous amounts every year. The recycling of these materials to produce organic fertilizers (as compost) is very important for increasing the agricultural production, reducing the application rates of chemical fertilizers and therefore the prevention of environmental pollution(Saleh et al 2003). The regular addition of compost is one the best 
Talha N. I. A. et al.

ways enhance soil organic and humic content, which helps to build a fertile soil structure. Such a soil structure makes better use of water and nutrients. It easier to till and, overall, is better able to achieve optimum yields on a long term basis (Keith and Jakie 2011). Gaber 2000 and Rangarajan et al., 2000 demonstrated through a filed study that organic fertilizers significantly increased $\mathrm{N}$ and $\mathrm{K}$ uptake and yield of legume crop.

The objective of the present work is to investigate the effects of $\mathrm{N}-$ mineral and organic fertilizers applaction with or without sulphur on soybean yield and its chemical composition, rather for soil contents of N, P and K for sustainable agriculture.

\section{MATERIALS AND METHODS}

A field experiment was carried out at Sakha Agriculture Research Station farm using soybean (Glycine max L.) during the two successive summer seasons of 2010and 2011. The soil of the experimental field was clayey in texture as shown in Table 1.Some soil chemical analysis was determined according to Page (1982) and physical properties of the soil were determined according to Klute (1986). Some properties of applied compost were presented in Table 2 .Split plot design was used. The main plots were assigned by three soybean cultivars, Crowford $\left(\mathrm{CV}_{1}\right)$, Giza $111\left(\mathrm{CV}_{2}\right)$, and Taiwan $\left(\mathrm{CV}_{3}\right)$. The sub -plots were allotted to four treatments (1) N fertilizer as urea at level of $15 \mathrm{~kg} \mathrm{Nfed}^{-1}$; (2) Rice straw compost at rate of $10 \mathrm{tonfed}^{-1}$; (3) Rice straw compost at rate of 10 ton fed ${ }^{-1}+$ sulphur at level of $400 \mathrm{kgfed}^{-1}$ as agriculture sulphur and (4) N fertilizer as urea at level of $15 \mathrm{~kg} \mathrm{Nfed}^{-1}+$ sulphur at level of $400 \mathrm{kgfed}^{-1}$. The treatments were replicated four times for each. All treatments were fertilized with super phosphate $\left(7 \mathrm{~kg} \mathrm{pfed}^{-1}\right)$ and potassium sulphute $\left(24 \mathrm{~kg} \mathrm{k}_{2} \mathrm{Ofed}^{-1}\right)$. The other recommended agriculture practices were done.

Studied characters:

1- Yield and its components: Biomass, seed yield (ton fed ${ }^{-1}$ ) and 100seed weight $(\mathrm{g})$.

2- Some mineral composition of soybean seed and straw: i.e., nitrogen, $p$ Phosphorus and potassium were determined according to method introduced by Jackson (1967). Protein percentage was calculated by multiplying the total nitrogen\% by 5.71 according (FAO/WHO.1973).

3- Nutrient contents (Available N, P and K) of representative surface soil samples $(0-15 \mathrm{~cm})$ after soybean harvesting were determined according to the standard methods (Page, 1982). harvest index was determined by the following:

Harvest index $=$ seed yield $\mathrm{kg} /$ biomass yield $\mathrm{kg}$

The data were subjected to statistical analysis according to (Snedecor and Cochran, 1980). 
J. Soil Sci. and Agric. Eng., Mansoura Univ., Vol. 3 (4), April, 2012

Table 1: Some characteristics of the experimental soil.

\begin{tabular}{|c|c|c|c|c|c|}
\hline Characteristics & $\begin{array}{c}\text { Season } \\
2010\end{array}$ & $\begin{array}{c}\text { Season } \\
2011 \\
\end{array}$ & Characteristics & $\begin{array}{c}\text { Season } \\
2010\end{array}$ & $\begin{array}{c}\text { Season } \\
2011 \\
\end{array}$ \\
\hline $\begin{array}{l}\mathrm{pH}(1: 2.5 \text { soil:water } \\
\text { suspensions) }\end{array}$ & 7.98 & 7.82 & \multicolumn{3}{|c|}{ Partials size distributions (\%) } \\
\hline $\begin{array}{c}\mathrm{EC}, \mathrm{dSm}^{-1} \text { (Soil paste) } \\
\text { at } 25^{\circ} \mathrm{C}\end{array}$ & 3.30 & 3.04 & Sand & 21.45 & 23.80 \\
\hline $\mathrm{OM} \%$ & 1.24 & 1.35 & Silt & 31.56 & 24.90 \\
\hline Soluble cations meql & & & Clay & 46.99 & 51.30 \\
\hline $\mathrm{Ca}^{++}$ & 10.05 & 13.42 & Texture class & clayey & clayey \\
\hline $\mathrm{Mg}^{++}$ & 3.69 & 8.86 & \multicolumn{3}{|c|}{ Available macronutrients $\mathrm{mgKg}^{-1}$} \\
\hline $\mathrm{Na}^{+}$ & 19.90 & 7.71 & $\mathrm{~N}$ & 28.50 & 30.50 \\
\hline $\mathrm{K}^{+}$ & 0.83 & 1.01 & $P$ & 7.77 & 8.50 \\
\hline Soluble anions meqL & & & $\mathrm{K}$ & 392.5 & 416.90 \\
\hline $\mathrm{CO}^{--}$ & - & - & $\mathrm{C} / \mathrm{N}$ & 10.23 & 11.00 \\
\hline $\mathrm{HCO}^{-}$ & 9.90 & 3.50 & Total CaCo3\% & 3.83 & 3.95 \\
\hline $\mathrm{CL}^{-}$ & 19.10 & 18.72 & CEC & 33.00 & 34.50 \\
\hline $\mathrm{SO}^{--}$ & 5.47 & 8.78 & $\begin{array}{l}\text { S.P. \%(saturation } \\
\text { percentage) }\end{array}$ & 79.72 & 78.50 \\
\hline
\end{tabular}

Table 2: Some characteristics of the used rice straw compost

\begin{tabular}{|c|c|c|c|}
\hline Characteristics & Values & Characteristics & Values \\
\hline \multicolumn{2}{|c|}{ Soluble cations meqL ${ }^{-1}$} & $\begin{array}{c}\text { pH (1:10 composts :water } \\
\text { suspension) }\end{array}$ & 6.51 \\
\hline $\mathrm{Ca}^{++}$ & 5.98 & $\begin{array}{c}\mathrm{EC}, \mathrm{dSm}^{-1}(1: 10 \text { composts } \\
\text { suspensions) }\end{array}$ & 2.31 \\
\hline $\mathrm{Mg}^{++}$ & 4.17 & $\mathrm{OM} \%$ & 58.15 \\
\hline $\mathrm{Na}^{+}$ & 4.95 & \multicolumn{2}{|c|}{ Total macronutrients \% } \\
\hline $\mathrm{K}^{+}$ & 10.47 & $\mathrm{~N}$ & 2.49 \\
\hline \multicolumn{2}{|c|}{ Soluble anions meqL $\mathrm{L}^{-1}$} & $\mathrm{P}$ & 1.08 \\
\hline $\mathrm{CO}_{3}^{--}$ & - & $\mathrm{K}$ & 2.22 \\
\hline $\mathrm{HCO}_{3}^{-}$ & 3.30 & $\mathrm{C} / \mathrm{N}$ & 13.98 \\
\hline $\mathrm{Cl}^{-}$ & 11.31 & $\mathrm{OC} \%$ & 33.74 \\
\hline $\mathrm{SO}_{4}^{-}$ & 10.96 & Available N \% & 0.15 \\
\hline
\end{tabular}

${ }^{*}$ The compost used in the second season was kept dry from the same compost used in the first season.

\section{RESULTS AND DISCUSSION}

Yield and some yield components:-

Data presented in Tables 3,4 and 5 show the effect of fertilization treatments, soybean cultivars and their interactions on soybean biomass, seed yields and 100 seeds weight in both seasons.

\section{Biomass:}

Analysis of variance showed highly significant effect of fertilization treatments on the biomass yield Table 3 the highest biomass yield (4.74 and 4.54 tonfed $^{-1}$ ) in the first and second seasons were obtained with using composted rice straw at rate of 10 tonfed $^{-1}$ combined with sulphur at rate of $400 \mathrm{kgfed}^{-1}(\mathrm{OM}+\mathrm{S})$. This may be due to that the sulphur reduced $\mathrm{pH}$ of the soil resulting in higher nutrient availability. Moreover improving soil physical condition and increasing nutrient availability by composted rice straw. Similar results were obtained by Talha( 2003) .Meanwhile the lowest values (4.41 and 4.19 tonfed-1) in the first and second seasons were recorded with the 
Talha N. I. A. et al.

treatments $(\mathrm{N}+\mathrm{S})\left(\mathrm{N}\right.$ at rate of $15 \mathrm{kgNfed}^{-1}+$ sulphur at rate $\left.400 \mathrm{kgfed}^{-1}\right)$ this may be due to presence of sulphur with urea make slow release nitrogen fertilizer which decrease available nitrogen at need time. The results were in agreement with those obtained by Knany et al.,(2004)who found that straw yield of faba bean at sulphur treatment clearly illustrates competitive effect between the nitrogen and sulphur which results in a low straw yield. The trends obtained for biomass yields of soybean as influenced by fertilizer treatments can be arranged as follows $\mathrm{OM}+\mathrm{S}>\mathrm{OM}>$ control $\mathrm{N}>\mathrm{N}+\mathrm{S}$ in the two seasons.

Table 3 : Effect of fertilization treatments on soybean biomass, seed yield tonfed ${ }^{-1}$, and 100 -seed weight $(\mathrm{g})$ in the first and second seasons

\begin{tabular}{|c|c|c|c|c|c|c|c|c|}
\hline \multirow{2}{*}{ Treatments } & \multicolumn{2}{|c|}{ Biomass } & \multicolumn{2}{|c|}{ Seed yield } & \multicolumn{2}{|c|}{ 100-seed weight } & \multicolumn{2}{|c|}{ Harvest index } \\
\hline & $1^{\text {st }}$ & $2^{\text {nd }}$ & $1^{\text {st }}$ & $2^{\text {nd }}$ & $1^{\text {st }}$ & $2^{\text {nd }}$ & $1^{\text {st }}$ & $2^{\text {nd }}$ \\
\hline Control (N) & 4.72 & 4.50 & 2.17 & 2.07 & 19.36 & 19.16 & 0.460 & 0.460 \\
\hline OM & 4.59 & 4.42 & 2.23 & 2.13 & 16.64 & 16.44 & 0.486 & 0.482 \\
\hline $\mathrm{OM}+\mathrm{S}$ & 4.74 & 4.54 & 2.42 & 2.29 & 16.18 & 15.98 & 0.511 & 0.504 \\
\hline $\mathrm{N}+\mathrm{S}$ & 4.41 & 4.19 & 2.00 & 1.89 & 17.29 & 17.09 & 0.454 & 0.451 \\
\hline F-test & ** & ** & ** & *夫 & ** & ** & ** & ** \\
\hline LSD0.05 & 0.11 & 0.17 & 0.09 & 0.10 & 0.08 & 0.08 & 0.015 & 0.015 \\
\hline
\end{tabular}

Data in Table 4 revealed that the soybean cultivars were different significantly in biomass yield in the two seasons. Crowford cultivars $\left(\mathrm{Cv}_{1}\right)$ had the highest values (4.77 and 4.57 ton/fed) in the first and second seasons followed by Giza111 cultivar ( 4.54 and 4.36 tonfed $^{-1}$ ) and the lowest values of (4.51 and 4.31 ton/fed) were recorded with Taiwan cultivars. These differences may be due to the differences in the genetic ground of the used cultivars which led to different response to fertilization treatments.

Table 4: Effect of soybean cultivars on biomass, seeds yields ton/fed and 100 -seed weight $(\mathrm{g})$ in the first and second seasons.

\begin{tabular}{|c|c|c|c|c|c|c|}
\hline \multirow{2}{*}{ Cultivars } & \multicolumn{3}{|c|}{ Biomass(ton/fed) } & \multicolumn{2}{c|}{ Seed yield(ton/fed) } & 100 seed weight(g) \\
\cline { 2 - 7 } & 1st & 2nd & 1st & 2nd & 1st & 2nd \\
\hline $\mathrm{CV}_{1}$ & 4.77 & 4.57 & 2.29 & 2.19 & 17.25 & 17.05 \\
\hline $\mathrm{Cv}_{2}$ & 4.54 & 4.36 & 2.13 & 2.03 & 16.86 & 16.66 \\
\hline $\mathrm{Cv}_{3}$ & 4.51 & 4.31 & 2.19 & 2.07 & 17.99 & 17.79 \\
\hline F-test & ${ }^{\star *}$ & ${ }^{\star *}$ & ${ }^{\star *}$ & ${ }^{\star *}$ & ${ }^{\star *}$ & ${ }^{\star *}$ \\
\hline LSD0.05 & 0.22 & 0.22 & 0.09 & 0.09 & 1.01 & 1.01 \\
\hline
\end{tabular}

Effect of the interaction between fertilization treatments and soybean cultivars had significant differences on biomass yield during the first and second seasons.

Table 5 show that the highest biomass yield (5.06 and 4.86 tonfed $\left.^{-1}\right)$ in the first and second seasons were obtained with application of $(\mathrm{OM}+\mathrm{S})$ treatment for Crowford cultivar $\left(\mathrm{Cv}_{1}\right)$ during both seasons respectively. 
Table 5: Effect of the interaction between fertilization and cultivars on soybean biomass, seed yields tonfed ${ }^{-1}$, and 100 seed weight $(\mathrm{g})$ in the first and second seasons.

\begin{tabular}{|c|c|c|c|c|c|c|}
\hline \multirow{2}{*}{ Treatments } & \multicolumn{3}{|c|}{$1^{\mathrm{st}}$} & \multicolumn{3}{|c|}{$2^{\text {nd }}$} \\
\hline & $\mathrm{Cv}_{1}$ & $\mathbf{C v}_{2}$ & $\mathbf{C v}_{3}$ & $\mathrm{Cv}_{1}$ & $\mathbf{C v}_{2}$ & $\mathbf{C v}_{3}$ \\
\hline \multicolumn{7}{|c|}{ Biomass yield $\left(\right.$ tonfed $\left.^{-1}\right)$} \\
\hline Control (N) & $4.80 \mathrm{~b}$ & $4.63 \mathrm{a}$ & $4.68 \mathrm{a}$ & $4.60 \mathrm{~b}$ & $4.43 \mathrm{a}$ & $4.48 \mathrm{a}$ \\
\hline OM & $4.77 \mathrm{~b}$ & $4.50 \mathrm{~b}$ & $4.50 \mathrm{ab}$ & $4.57 \mathrm{~b}$ & $4.44 \mathrm{a}$ & $4.31 \mathrm{a}$ \\
\hline $\mathrm{OM}+\mathrm{S}$ & $5.06 \mathrm{a}$ & $4.66 \mathrm{a}$ & $4.52 a b$ & $4.86 \mathrm{a}$ & $4.46 \mathrm{a}$ & $4.32 \mathrm{a}$ \\
\hline $\mathrm{N}+\mathrm{S}$ & $4.47 \mathrm{c}$ & $4.39 \mathrm{~b}$ & $4.38 \mathrm{~b}$ & $4.27 \mathrm{c}$ & $4.19 \mathrm{~b}$ & $4.13 \mathrm{~b}$ \\
\hline \multicolumn{7}{|c|}{ Seed yield (tonfed ${ }^{-1}$ ) } \\
\hline Control (N) & $2.17 \mathrm{c}$ & $2.13 \mathrm{~b}$ & $2.21 \mathrm{~b}$ & $2.09 \mathrm{c}$ & $2.03 \mathrm{~b}$ & $2.11 \mathrm{~b}$ \\
\hline $\mathrm{OM}$ & $2.43 \mathrm{~b}$ & $2.10 \mathrm{~b}$ & $2.15 \mathrm{~b}$ & $2.33 \mathrm{~b}$ & $2.00 \mathrm{~b}$ & $2.05 \mathrm{~b}$ \\
\hline $\mathrm{OM}+\mathrm{S}$ & $2.54 \mathrm{a}$ & $2.31 \mathrm{a}$ & $2.39 \mathrm{a}$ & $2.44 \mathrm{a}$ & $2.21 \mathrm{a}$ & $2.23 \mathrm{a}$ \\
\hline $\mathrm{N}+\mathrm{S}$ & $2.01 \mathrm{~d}$ & $1.97 \mathrm{c}$ & $2.01 \mathrm{c}$ & $1.91 \mathrm{~d}$ & $1.87 \mathrm{c}$ & $1.90 \mathrm{c}$ \\
\hline \multicolumn{7}{|c|}{ 100-Seed weight (g.) } \\
\hline Control (N) & $18.50 \mathrm{a}$ & $18.44 \mathrm{a}$ & $21.14 \mathrm{a}$ & $18.30 \mathrm{a}$ & $18.24 \mathrm{a}$ & $20.94 \mathrm{a}$ \\
\hline $\mathrm{OM}$ & $16.60 \mathrm{~b}$ & $16.53 \mathrm{~b}$ & $16.78 \mathrm{~b}$ & $16.40 \mathrm{~b}$ & $16.33 \mathrm{~b}$ & $16.58 \mathrm{~b}$ \\
\hline $\mathrm{OM}+\mathrm{S}$ & $15.92 b$ & $15.74 \mathrm{~b}$ & $16.87 \mathrm{~b}$ & $15.72 b$ & $15.54 \mathrm{~b}$ & $16.67 b$ \\
\hline $\mathrm{N}+\mathrm{S}$ & $17.97 \mathrm{a}$ & $16.72 \mathrm{~b}$ & $17.17 b$ & $17.77 \mathrm{a}$ & $16.52 \mathrm{~b}$ & $16.97 \mathrm{~b}$ \\
\hline
\end{tabular}
DMRT.

\section{Seeds yield:}

Analysis of variance showed high significantly effect of fertilization treatments on seeds yield in the two seasons. It could be noticed from Table 3 that composted rice straw combined with sulphur treatment $(\mathrm{OM}+\mathrm{S})$ caused a markedly positive effect on seed yield ( 2.42 and 2.29 tonfed $\left.^{-1}\right)$ in the first and second season as compared with $(\mathrm{N}+\mathrm{S})$ treatment which recorded the lowest values (2.00 and 1.89 tonfed $^{-1}$, respectively). The trend obtained for seed yield as influenced by fertilization treatments are similar to these obtained for biomass yield. Data in Table 4 show high significantly effect on seed yield by soybean cultivars. The seed yield as affected by cultivars can be arranged as follow : Manner Crowford cultivar $\left(\mathrm{Cv}_{1}\right)>$ Taiwan $\left(\mathrm{Cv}_{3}\right)>$ Giza111 $\left(\mathrm{Cv}_{2}\right)$. This result prove that soybean crowford cultivar is superior to

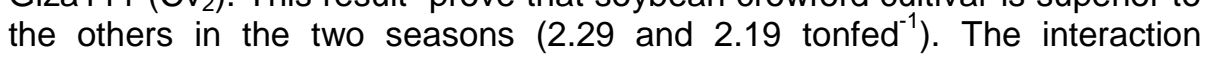
between fertilization treatments and soybean cultivars had highly significant effect on soybean seed yield in both seasons. The highest seed yield was obtained by $\mathrm{Cv}_{1}$ under $\mathrm{OM}+\mathrm{S}$ treatment (2.54 and 2.44 tonfed $\left.^{-1}\right)$.Similar results were obtained by Talha 2003.

\section{0-seed weight:}

Data in Table 3 show a highly significant effect of fertilization treatments on soybean 100-seed weight in the two seasons. The highest values of 19.36 and $19.16 \mathrm{~g}$ were obtained with the control treatment $\left(\mathrm{N}\right.$ at rate $\left.15 \mathrm{~kg} \mathrm{~N}^{-1} \mathrm{fed}^{-1}\right)$. Whereas, the lowest values of 16.18 and $15.98 \mathrm{~g}$ were recorded with $(\mathrm{OM}+\mathrm{S})$ treatment in the first and second seasons, respectively. This may be due to $(\mathrm{OM}+\mathrm{S})$ treatment enhanced bods formation which produce high number of bods / plant which affected seed filling. The obtained results are in agreement those obtaind by with Mohammadi et al., 2011, who stated that nitrogen plays an important role in grain filling .Soybean 100-seed weight was high significantly affected by soybean cultivars. The highest values of 17.99 and 
Talha N. I. A. et al.

$17.79 \mathrm{~g}$ were obtained by Taiwan cultivar followed by Crowford cultivar of (17.25 and $17.05 \mathrm{~g})$ and the lowest values of $(16.86$ and $16.66 \mathrm{~g})$ were recorded with Giza 111 cultivar in the first and second season respectively. The effect of the interaction between fertilization treatments and soybean cultivars on 100-seed weight was highly significant in both seasons. The highest values were obtained under $\mathrm{N}$ treatment for all cultivars in the two seasons.

\section{Nitrogen content of seeds:}

Fertilizer treatments had highly significant effect on $\mathrm{N}$-content of soybean seeds in both seasons (Table 6).

Nitrogen content as affected by fertilization treatments can be arranged as follow $\mathrm{OM}>\mathrm{N}>\mathrm{OM}+\mathrm{S}>\mathrm{N}+\mathrm{S}$. These results were in line with available $\mathrm{N}$ in the soil. This could be explained on the fact that, the release of nitrogen $\mathrm{N}\left(\mathrm{NO}_{3}\right.$, and $\left.\mathrm{NH}_{4}\right)$ was higher due to lower the $\mathrm{C} / \mathrm{N}$ ratio of the added compost to soil 13.98 (Mengel and Kirkby 1982). The decreasing of Ncontent by soybean seed yield as affected by $\mathrm{OM}+\mathrm{S}$ treatment is probably due to presence of sulphur increased nitrogen utilization efficiency which led to increase seed yield with low nitrogen content. Soybean cultivars significantly affect $\mathrm{N}$-content in soybean seeds in the first and second season (Table 7), the highest values of 198.53 and $179.62 \mathrm{~kg} \mathrm{Nfed}^{-1}$ were obtained with $\mathrm{Cv}_{1}$ in the first and second seasons, respectively.

Table 6: Effect of fertilization treatments on $\mathrm{N}, \mathrm{P}$ and $\mathrm{K}$ contents of soybean seeds $\left(\mathrm{kgfed}^{-1}\right)$ in the two seasons.

\begin{tabular}{|c|c|c|c|c|c|c|}
\hline \multirow{3}{*}{ Treatments } & \multicolumn{6}{|c|}{ Seed content Kgfed ${ }^{-1}$. } \\
\hline & \multicolumn{2}{|c|}{$\mathbf{N}$} & \multicolumn{2}{|c|}{$\mathbf{P}$} & \multicolumn{2}{|c|}{$\mathbf{K}$} \\
\hline & $1^{\mathrm{st}}$ & $2^{\text {nd }}$ & $1^{\text {st }}$ & $2^{\text {nd }}$ & $1^{\mathrm{st}}$ & $2^{\text {nd }}$ \\
\hline Control(N) & 189.88 & 169.80 & 36.07 & 33.25 & 44.0 & 37.99 \\
\hline $\mathrm{OM}$ & 202.99 & 183.23 & 41.39 & 37.97 & 44.67 & 41.75 \\
\hline $\mathrm{OM}+\mathrm{S}$ & 185.99 & 166.80 & 37.28 & 33.78 & 41.96 & 39.43 \\
\hline $\mathrm{N}+\mathrm{S}$ & 180.76 & 163.52 & 29.87 & 27.23 & 36.21 & 33.67 \\
\hline F-test & ** & ** & ** & ** & ** & ** \\
\hline LSD0.05 & 9.28 & 8.63 & 2.31 & 1.72 & 2.17 & 2.18 \\
\hline
\end{tabular}

Table 7: Effect of soybean cultivars on $\mathrm{N}, \mathrm{P}$ and $\mathrm{K}$ contents of soybean seeds $\left(\mathrm{kgfed}^{-1}\right)$ in the two seasons.

\begin{tabular}{|c|c|c|c|c|c|c|}
\hline \multirow{3}{*}{ Cultivars } & \multicolumn{6}{|c|}{ Seed content $\mathrm{Kgfed}^{-1}$. } \\
\hline & \multicolumn{2}{|c|}{$\mathbf{N}$} & \multicolumn{2}{|c|}{$\mathbf{P}$} & \multicolumn{2}{|c|}{ K } \\
\hline & $1^{\text {st }}$ & $2^{\text {nd }}$ & $1^{\text {st }}$ & $2^{\text {nd }}$ & $1^{\text {st }}$ & $2^{\text {nd }}$ \\
\hline $\mathrm{Cv}_{1}$ & 198.53 & 179.62 & 39.48 & 36.23 & 42.95 & 40.48 \\
\hline $\mathrm{Cv}_{2}$ & 182.54 & 164.54 & 34.51 & 31.72 & 38.94 & 36.50 \\
\hline $\mathrm{Cv}_{3}$ & 188.65 & 168.38 & 34.47 & 31.22 & 40.54 & 37.65 \\
\hline F-test & $\star \star \star$ & ** & ** & ** & ** & ** \\
\hline LSD0.05 & 7.44 & 4.68 & 2.47 & 2.18 & 2.66 & 2.31 \\
\hline
\end{tabular}

The interaction between fertilization treatments and soybean cultivars Table 8 show that the highest $\mathrm{N}$ - content of seeds was recorded with $\mathrm{Cv}_{3}$ and $\mathrm{Cv}_{1}$ under $\mathrm{OM}$ treatment in the first and second seasons, respectively. 


\section{Phosphorus content of seeds:}

Data in Table 6 show that a highly significant effect of fertilization treatments on P-content of soybean seeds in the two seasons. Phosphorus content as affected by fertilization treatments can be arranged in decreasing order as follow $\mathrm{OM}>\mathrm{OM}+\mathrm{S}>\mathrm{N}>\mathrm{N}+\mathrm{S}$. This may be due to $\mathrm{OM}$ led to increase total count of soil microorganisms which increase phosphours solubilizing on the other hand, presence of sulphur decrease some fungi sp. Similar results were reported by (Sui and Thompson, 2000) who concluded that organic soil amendments, such as vegetative mulches, reduce the sorption of $P$ in soil and increase the equilibrium $P$ concentration in the soil solution. Data in Table 13 confirm the previous results, the highest available phosphorus were recorded by OM treatment in the both seasons. Data in Table 7 show a highly significant effect of soybean cultivars on P-content by seeds in the two seasons. The highest values of 39.48 and $36.23 \mathrm{~kg} \mathrm{Pfed}^{-1}$ were obtained by $\mathrm{Cv}_{1}$ cultivar in the first and second seasons, respectively .This may be due to $\mathrm{Cv}_{1}$ cultivar has high root system compared with the other used varieties which absorb more $P$.

The interaction between fertilization treatments and soybean cultivars Table 8 showed that the highest $\mathrm{P}$-content seed yield was obtained by $\mathrm{Cv}_{1}$ under OM treatment in both seasons.

Table 8: Effect of the interaction between fertilization treatments and soybean cultivars on $\mathrm{N}, \mathrm{P}$ and $\mathrm{K}$ content of soybean seeds $\left(\right.$ kgfed $\left.^{-1}\right)$.

\begin{tabular}{|c|c|c|c|c|c|c|}
\hline \multirow{2}{*}{ treatments } & \multicolumn{3}{|c|}{$1^{\text {st }}$} & \multicolumn{3}{|c|}{$2^{\text {nd }}$} \\
\hline & $\mathbf{C v}_{1}$ & $\mathbf{C v}_{2}$ & $\mathbf{C v}_{3}$ & $\mathbf{C v}_{1}$ & $\mathbf{C v}_{2}$ & $\mathbf{C v}_{3}$ \\
\hline \multicolumn{7}{|c|}{ N-content kgfed ${ }^{-1}$} \\
\hline Control (N) & $191.54 a$ & $189.47 a$ & $188.23 b$ & $169.45 b$ & 169.60ab & $170.35 a b$ \\
\hline $\mathrm{OM}$ & $208.65 a$ & $192.50 \mathrm{a}$ & $209.81 a$ & $192.52 a$ & $173.12 \mathrm{a}$ & $184.06 a$ \\
\hline $\mathrm{OM}+\mathrm{S}$ & $203.57 a$ & $172.31 \mathrm{~b}$ & $182.11 b$ & 182.10ab & $154.10 \mathrm{~b}$ & $163.53 b$ \\
\hline $\mathrm{N}+\mathrm{S}$ & 191.99a & $174.81 \mathrm{~b}$ & $174.44 b$ & $174.42 b$ & $160.54 a b$ & $155.60 \mathrm{~b}$ \\
\hline \multicolumn{7}{|c|}{ P- content kgfed ${ }^{-1}$} \\
\hline Control (N) & $37.36 \mathrm{c}$ & $33.57 b$ & $37.29 a$ & $34.63 c$ & $30.78 \mathrm{c}$ & $34.33 a$ \\
\hline $\mathrm{OM}$ & $46.91 \mathrm{a}$ & $40.81 \mathrm{a}$ & $36.45 a$ & $43.61 \mathrm{a}$ & $37.71 \mathrm{a}$ & $32.60 a$ \\
\hline $\mathrm{OM}+\mathrm{S}$ & $43.59 b$ & $35.35 b$ & $32.90 \mathrm{~b}$ & $39.26 b$ & $32.51 b$ & $29.36 c$ \\
\hline $\mathrm{N}+\mathrm{S}$ & $30.05 d$ & $28.31 \mathrm{c}$ & $31.23 b$ & 27.41 & $25.89 d$ & $28.39 c$ \\
\hline \multicolumn{7}{|c|}{ K- content kgfed ${ }^{-1}$} \\
\hline Control (N) & $41.71 b$ & $39.31 b$ & $40.17 b$ & $39.45 b$ & $36.85 b$ & $37.68 a$ \\
\hline OM & $47.68 \mathrm{a}$ & $42.73 a$ & $43.61 a$ & $45.07 a$ & $40.22 a$ & $39.96 a$ \\
\hline $\mathrm{OM}+\mathrm{S}$ & $46.25 a$ & $38.65 b$ & $40.98 b$ & $43.63 a$ & $36.21 b$ & $38.46 a$ \\
\hline $\mathrm{N}+\mathrm{S}$ & $36.15 c$ & $35.08 \mathrm{c}$ & $37.39 c$ & $33.78 \mathrm{c}$ & $32.74 \mathrm{c}$ & $34.50 \mathrm{~b}$ \\
\hline
\end{tabular}

Means followed by a common letter are not significantly different at the $5 \%$ by DMRT.

\section{Potassum content of seeds:}

The results in Table 6 show a highly significant effect of fertilization treatment on $\mathrm{K}$ content in seeds in the two seasons. The highest values (44.67 and $41.75 \mathrm{~kg} / \mathrm{fed}^{-1}$ ) were obtained by OM treatment in the first and second seasons, respectively. The obtained data confirmed the absolute superiority of the OM treatment in increasing the available potassium(Table 13). The results could be explained on the fact that , the cation exchange 
Talha N. I. A. et al.

capacity (CEC) of soil increases as OM\% increases, consequently, the availability of $\mathrm{Ca}^{2+}, \mathrm{Mg}^{2+}, \mathrm{K}^{+}$, and $\mathrm{Na}^{+}$increases (Magdoff and well 2004). $\mathrm{K}$ content by soybean seeds was high significantly affected by soybean cultivars and can be arranged in decreasing order $\mathrm{Cv}_{1}>\mathrm{Cv}_{3}>\mathrm{Cv}_{2}$. The interaction between the studies parameter gave significant effect on $\mathrm{K}$ content by seeds in the two seasons. The highest values $(47.68$ and $45.07 \mathrm{~kg}$ $\mathrm{k} / \mathrm{fed}$ ) were obtained by $\mathrm{Cv}_{1}$ under $\mathrm{OM}$ treatment in the first and second seasons, respectively.

\section{Nutrients content in soybean straw:}

Data in Table 9 show that fertilization treatments gave a highly significant effect on N, P and $\mathrm{K}$ content by straw in both seasons. This trend in nutrients content by straw yield among the treatments was different for seeds. The highest $\mathrm{N}$ and $\mathrm{P}$ content by straw were obtained with the control treatment $\left(40.25\right.$ and $\left.31.74 \mathrm{~kg} \mathrm{~N} \mathrm{fed}^{-1}\right)$ and $\left(12.74\right.$ and $\left.11.42 \mathrm{~kg} \mathrm{P}^{-1}\right)$ in the first and second seasons respectively. While the lowest $\mathrm{N}$ and $\mathrm{P}$-content were recorded with $(\mathrm{N}+\mathrm{S})$ treatment $\left(36.00\right.$ and $27.62 \mathrm{~kg} \mathrm{~N}$ fed $\left.^{-1}\right)$ and $(9.06$

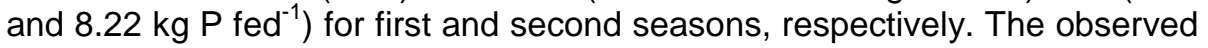
reduction in $\mathrm{N}$ and $\mathrm{P}$-content by soybean straw could be explained by Chandrasekar et al. (2005), who concluded that developing seed utilize nitrogen and $P$ from the vegetative parts for the syenthesis of storage and non storage grain proteins. On the other hand the highest values of $\mathrm{K}$ content by straw were recorded with $\mathrm{OM}+\mathrm{S}$ treatment $(40.90$ and $37.82 \mathrm{~kg} \mathrm{~K}$ $\left.\mathrm{fed}^{-1}\right)$ in the first and second seasons, respectively. While OM treatment recorded the lowest values (33.51 and $\left.30.73 \mathrm{~kg} \mathrm{Kfed}^{-1}\right)$.

Table 9: Effect of fertilization treatments on $\mathrm{N}, \mathrm{P}$ and $\mathrm{K}$ contents in soybean straw $\left(\mathrm{kgfed}^{-1}\right)$ in the two seasons

\begin{tabular}{|c|c|c|c|c|c|c|}
\hline \multirow{3}{*}{ Treatments } & \multicolumn{6}{|c|}{${\text { Nutrients content } \mathrm{Kgfed}^{-1}}^{-1}$} \\
\hline & \multicolumn{2}{|c|}{ N-content } & \multicolumn{2}{|c|}{ P-content } & \multicolumn{2}{|c|}{ K- content } \\
\hline & $1 \mathrm{st}$ & 2nd & $1 \mathrm{st}$ & 2nd & $1 \mathrm{st}$ & 2nd \\
\hline Control(N) & 40.25 & 31.74 & 12.74 & 11.42 & 39.17 & 36.17 \\
\hline $\mathrm{OM}$ & 39.28 & 31.05 & 11.34 & 10.41 & 33.51 & 30.73 \\
\hline $\mathrm{OM}+\mathrm{S}$ & 39.07 & 30.27 & 10.33 & 9.51 & 40.90 & 37.82 \\
\hline $\mathrm{N}+\mathrm{S}$ & 36.00 & 27.62 & 9.06 & 8.22 & 35.06 & 32.22 \\
\hline F-test & ** & ** & ** & ** & ** & ** \\
\hline LSD0.05 & 2.96 & 2.79 & 1.00 & 0.72 & 2.97 & 2.85 \\
\hline
\end{tabular}

Data in Table 10 show that soybean cultivars had no significant effect on $\mathrm{N}$ - content by straw in the first season, while it had highly significant effect in the second season. Soybean cultivars had no significant effect in P content by straw yield in both seasons, on the other hand, it had highly significant effect on $\mathrm{K}$ - content as shown in Table 10 the highest values of ( 39.32 and $36.32 \mathrm{~kg} \mathrm{k}$ fed $^{-1}$ ) were obtained with $\mathrm{Cv}_{1}$ in the first and second seasons, respectively this may be due to $\mathrm{Cv}_{1}$ is highest vegetative growth which reflected on the nutrients content. 
Table 10: Effect of soybean cultivars on $N, P$ and $K$ content of soybean straw kgfed ${ }^{-1}$ in the two seasons

\begin{tabular}{|c|c|c|c|c|c|c|}
\hline \multirow{3}{*}{ Cultivars } & \multicolumn{6}{|c|}{ 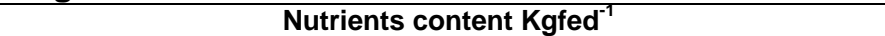 } \\
\hline & \multicolumn{2}{|c|}{$\mathrm{N}$-content } & \multicolumn{2}{|c|}{ P- content } & \multicolumn{2}{|c|}{ K- content } \\
\hline & & 2nd & & 2nd & & 2nd \\
\hline $\mathrm{Cv}_{1}$ & 38.24 & 29.47 & 10.78 & 9.86 & 39.33 & 36.32 \\
\hline $\mathrm{Cv}_{2}$ & 38.55 & 29.99 & 10.82 & 9.90 & 36.57 & 33.67 \\
\hline $\mathrm{Cv}_{3}$ & 39.16 & 31.04 & 11.01 & 9.90 & 35.58 & 32.72 \\
\hline F-test & NS & ** & NS & NS & ** & ** \\
\hline LSD0.05 & - & 2.48 & - & - & 2.90 & 2.78 \\
\hline
\end{tabular}

Data in Table 11 show the effect of interaction between fertilization and soybean cultivars on N, P and $\mathrm{K}$ contents of soybean straw.

$\mathrm{N}$-content of straw was affected significantly by the interaction between the studied factors. The highest values $\left(43.30\right.$ and $\left.34.91 \mathrm{~kg} \mathrm{Nfed}^{-1}\right)$ were recorded with $\mathrm{Cv}_{3}$ under $\mathrm{OM}$ treatment in the first and second seasons respectively. While $\mathrm{P}$-content of straw was not affected significantly by the interaction Table 11 Potassum content of straw significantly affected by the interaction between fertilization treatments and soybean cultivars in the first and second seasons. The highest values (42.85 and $39.70 \mathrm{~kg} \mathrm{Kfed}^{-1}$ ) were obtained by $\mathrm{Cv}_{1}$ under $\mathrm{OM}+\mathrm{S}$ treatment.

Table 11: Effect of the interaction between fertilization treatments and soybean cultivars on $\mathrm{N}, \mathrm{P}$ and $\mathrm{K}$ contents of soybean straw $\left(\mathrm{kgfed}^{-1}\right)$ in the two seasons.

\begin{tabular}{|c|c|c|c|c|c|c|}
\hline & \multicolumn{3}{|c|}{$1 \mathrm{st}$} & \multicolumn{3}{|c|}{ 2nd } \\
\hline & $\mathrm{Cv}_{1}$ & $\mathrm{Cv}_{2}$ & $\mathrm{Cv}_{3}$ & $\mathrm{Cv}_{1}$ & $\mathrm{Cv}_{2}$ & $\mathbf{C v}_{3}$ \\
\hline \multicolumn{7}{|c|}{$\mathrm{N}$-content } \\
\hline Control (N) & $38.31 \mathrm{ab}$ & $40.16 a$ & $42.29 a$ & $28.97 a b$ & $31.34 a$ & $34.91 \mathrm{a}$ \\
\hline $\mathrm{OM}$ & $38.15 a b$ & $36.37 b$ & $43.30 a$ & $30.08 a$ & $28.36 a$ & $34.61 a$ \\
\hline $\mathrm{OM}+\mathrm{S}$ & $40.85 \mathrm{a}$ & $37.80 \mathrm{a}$ & $38.57 b$ & $31.73 a$ & $28.95 a$ & $30.13 b$ \\
\hline $\mathrm{N}+\mathrm{S}$ & $35.64 b$ & $39.88 b$ & $32.46 c$ & $27.11 \mathrm{~b}$ & $31.32 a$ & $24.43 c$ \\
\hline \multicolumn{7}{|c|}{ P-content } \\
\hline Control (N) & $12.67 a$ & $12.61 \mathrm{a}$ & $12.933 a$ & $11.66 a$ & $11.63 a$ & $10.94 a$ \\
\hline OM & $11.98 a$ & $11.28 \mathrm{a}$ & $10.77 a$ & $11.02 \mathrm{a}$ & $10.34 a$ & $9.90 \mathrm{a}$ \\
\hline $\mathrm{OM}+\mathrm{S}$ & $9.91 a$ & $10.57 a$ & $10.50 a$ & $9.03 a$ & $9.64 a$ & $9.85 a$ \\
\hline $\mathrm{N}+\mathrm{S}$ & $8.54 a$ & $8.85 a$ & $9.83 a$ & $7.73 a$ & $7.99 a$ & $8.96 a$ \\
\hline \multicolumn{7}{|c|}{ K- content } \\
\hline Control (N) & $41.79 a$ & $37.64 a b$ & $38.10 a$ & $38.69 a$ & $34.59 a b$ & $35.14 a$ \\
\hline $\mathrm{OM}$ & $34.30 c$ & $32.64 c$ & $33.58 b$ & $31.48 \mathrm{c}$ & $29.90 c$ & $30.81 b$ \\
\hline $\mathrm{OM}+\mathrm{S}$ & $42.85 a$ & $39.99 a$ & $39.85 a$ & $39.70 \mathrm{a}$ & $36.95 a$ & $36.81 a$ \\
\hline $\mathrm{N}+\mathrm{S}$ & $38.38 b$ & $36.01 b$ & $30.80 \mathrm{~b}$ & $35.41 b$ & $33.12 b$ & $28.13 b$ \\
\hline
\end{tabular}

Means followed by a common letter are not significantly different at the $5 \%$ level by DMRT

Protein percentage (\%) of seeds:

Data in Table 12 show that the fertilization treatments had highly significant effect in protein percentage of seeds. The highest mean values of the ,treatment (51.80 and $48.98 \%)$ in the first and second seasons respectively were recorded with $\mathrm{N}+\mathrm{S}$ treatment. The results could be explained on the fact that, sulphur as essential mineral nutrient play key roles in protein production Chandel et al. (2003). Mengel and kirkby (1982) illustrated the essential role of $\mathrm{S}$ in promoting growth and $\mathrm{N}$ fixation by 
Talha N. I. A. et al.

leguminous plants. Soybean cultivars and interaction between the treatment and cultivars had no significant effect on protein (\%) in the seeds.

Table 12: Effect of fertilization treatments, soybean cultivars and the interaction between them on protein \% of seeds in the two seasons

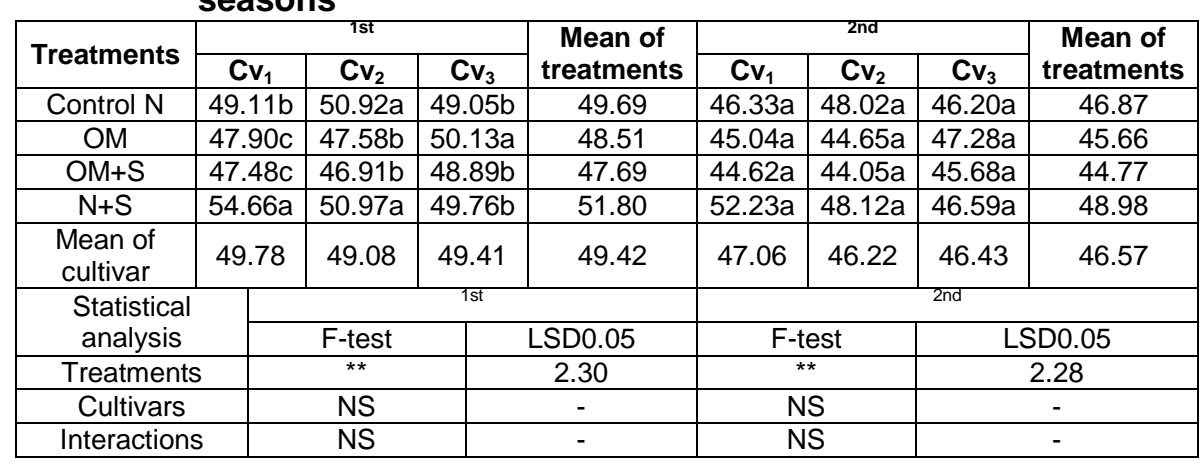

Effect of fertilization treatments on soil properties after soybean

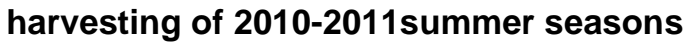

Soil organic matter:

Data in Table 13 show that soil organic matter content was increased after harvesting soybean plants in both seasons due to compost application , such increasing was arranged in the following descending order; $\mathrm{OM}+\mathrm{S}>\mathrm{OM}$ $>\mathrm{N}+\mathrm{S}>\mathrm{N}$. This may be due to presence of the residual OM from the compost of rice straw . These results are supported by Talha et al. (2007).

Soil pH:

Soil $\mathrm{pH}$ is probably the most commonly measured, as well as one of the most useful chemical properties. It helps to predict the relative availability of most inorganic nutrients. Data in Table 13 show that soil pH values slightly decreased after application of the different treatments in the compared with the control. The soil pH decreased from 8.25 and 8.21 (control) to 7.83 and 7.81 in treatment of $(\mathrm{OM}+\mathrm{S})$ in both seasons. The favorable effect of sulphur on reducing soil $\mathrm{pH}$ values might be due to the action of acidity produced as a result of sulphur oxidation to sulphuric acid by soil microorganisms, thus providing more $\mathrm{H}^{+}$ions in soil (Abd-Allahh1998).

Soil salinity:

Effect of different fertilization treatments with or without sulphur on soil salinity after harvesting soybean plants are shown in Table 13. Data show that addition of sulphur amendments $(\mathrm{N}+\mathrm{S})$ increased soil salinity as reflected on the EC of soil paste extracts. The values of EC slightly increased from (3.40to 4.70 and 3.48 to 4.36 ) in the two seasons of treatments ( $\mathrm{N}$ and $\mathrm{N}+\mathrm{S}$ ) respectively. This may be due to the dissolving action of sulphuric acid resulted from sulphur oxidation by microbial activity which reaction the $\mathrm{CaCO}_{3}$ and calcium phosphates and ends up with the formation of $\mathrm{CaSO}_{4}$, total salinity is thus increased. The same conclusions were reported by (AbdAllahh1998). 
Available soil macronutrients contents:

Data in Table 13 reveale that the fertilization treatments clearly affects the availability of $\mathrm{N}, \mathrm{P}$ and $\mathrm{K}$ after harvesting of soybean plants.Available N, P and $\mathrm{K}$ content in soil were increased up to 163.10; $174.41,18.87 ; 26.64$ and $503.10,577.2 \mathrm{mg} / \mathrm{kg}$ for OM in the two seasons. It was noticed that soil available nutrients contents resulting from the application of composted rice straw. This may be due to the growth period of soybean is short time which reflect residual of nutrients from, OM decomposition. Thus highly levels were interpreted by many others, Metwally and Khamis (1998) stated that organic maturing plays role in increasing the $\mathrm{N}$ availability through microorganism activity besides decreasing $\mathrm{N}$ losses by leaching and volatilization. The increase in the availability of soluble $\mathrm{P}$ from additions of compost which has an effect that described as resulting from phosphohumic complexes that minimize immobilization processes, anion replacement of phosphate by humatc ions, and coating of sesquioxide particles by humus to form a cover which reduces the phosphate fixating capacity (Rechcing1995).

Concerning the increasing of available $\mathrm{K}^{+}$after addition of compost, Tan (1993) found that humic and fulvic acids are capable for dissolving very small amounts potassium from the soil minerals by chelating complex reaction or both with released amounts of $\mathrm{K}$ being increased by time.

Table 13: Effect of fertilization treatment, on the soil properties after soybean harvesting of 2010-2011seseans

\begin{tabular}{|c|c|c|c|c|c|c|c|c|c|c|c|c|}
\hline \multirow[t]{2}{*}{ Treatments } & \multicolumn{2}{|c|}{ pH } & \multicolumn{2}{|c|}{$\begin{array}{c}E C \\
\left(\mathrm{dSm}^{-1}\right)\end{array}$} & \multicolumn{2}{|c|}{$\begin{array}{l}\text { OM } \\
\%\end{array}$} & \multicolumn{2}{|c|}{$\begin{array}{c}\mathrm{N} \text { available } \\
\left(\mathrm{mgKg}^{-1}\right)\end{array}$} & \multicolumn{2}{|c|}{$\begin{array}{c}\text { P available } \\
\left(\mathrm{mgKg}^{-1}\right)\end{array}$} & \multicolumn{2}{|c|}{$\begin{array}{c}\text { K available } \\
\left(\mathrm{mgKg}^{-1}\right)\end{array}$} \\
\hline & 2010 & 2011 & 2010 & 2011 & 2010 & 2011 & 2010 & 2011 & 2010 & 2011 & 2010 & 2011 \\
\hline Control(N) & 8.25 & 8.21 & 3.40 & 3.48 & 1.40 & 1.58 & 81.55 & 81.55 & 16.65 & 25.53 & 417.3 & 412.4 \\
\hline OM & 7.88 & 7.91 & 3.28 & 3.40 & 1.70 & 2.00 & 163.1 & 174.41 & 18.87 & 26.64 & 503.1 & 577.2 \\
\hline $\mathrm{OM}+\mathrm{S}$ & 7.83 & 7.81 & 3.40 & 3.34 & 1.83 & 2.02 & 89.71 & 97.86 & 16.55 & 20.53 & 401.7 & 432.9 \\
\hline $\mathrm{N}+\mathrm{S}$ & 8.16 & 8.01 & 4.70 & 4.36 & 1.59 & 1.81 & 48.93 & 50.00 & 15.54 & 24.42 & 357.7 & 382.7 \\
\hline
\end{tabular}

\section{REFERENCES}

Abd-Allah, M. A. A. (1998). Influence of sulphur and organic manures application on yield of sugar beet, subsequent crops \& some chemical properties of salt affected soils. (Ph.D.) Thesis, Fac. of Agric., Kafr EL-Sheikh. Tanta Univ. Egypt.

Agrisent: Manures http,/ sikkimagrisent.org/general/en/manures-fertilizers aspx.printertion 12/12/2011

Chandel , R. S.; P. C. Sudhakar; and K. Slingh (2003). Response of sulphur in rice $-A$ review.Agric. Res.24:167.

Chandrasekar,B.R.,G.Ambrose, and N.Gayabain(2005). Influence of biofertilizers and nitrogen source level on the growth and yield of Echinochloo frumentucea(Roxb)Link,J.Agricultural Technology 1(2):223

F.A.O/WHO (1973). Committee on Energy and Protein 
Talha N. I. A. et al.

Gaber, S. M. (2000). Effect of some organic fertilizers on growth yield and quality of some new soybean cultivars. Alex. J. Agric. Res. 45(2): 201212.

Jackson, M. L. (1967) "Soil Chemical Analysis "Pretic Hall India Part.I.E d.,New Delhi, India.

Keith,R.Baldwin and Greenfield T. Jackie(2011). Composting on organic farms .http; / heartspring .net / composting on organic farms.htm/.

Klute, A. (1986). Methods of Soil Analysis. Part1: Physical and mineralogical methods ( $2^{\text {nd }} E d$.) Am. Soc. Agron. In Soil Sci. Soc. Am. Inc. Medison. Wisconsim, USA.

Knany,R.E; A.M.Masoud and Y.B.EL-Waraky(2004). Comparative study between bio fertilization and sulphur on availability of added phosphorus to faba bean plants under high $\mathrm{pH}$ soil conditions.J.Agric.Sci.Mansoura Univ., 29 (8):4801- 4809.

Magdoff F. and R. R. Well (2004). Soil Organic Matter Sustainable Agriculture. CRC.Prass.LLC

Mengel,K. and E.A.Kirkby(1982). Principles of Plant Nutrition .Publ.potash Inst.,Bern.Swizerland.

Metwally, SH. M. and M.A.Khamis (1998). Comparative effects of organic and inorganic nitrogen sources applied to a sandy soil on availability of $\mathrm{N}$ and wheat yield. Egypt.J.Soil Sci.38 (1-4) 35.

Mohamed, Amal.A.; E.N. Gendy; KH.A. Asslely and Kh.B.M. Salem(2001). The effect of sulphur and manganese foliar application on lupine (lupinus terms L.) yield and its main component" J.Agric. Sci. Mansoura Univ., 26(1): 529.

Mohammadi, K; A. Ghalavand; M. Aghaalikhani; G. Heidari and Y. Sohrabi (2011). Introducing a sustainable soil fertility system for chickpea (Cicer arietinm L.). African gornal of Biotechnology 10(32):6011- 6020

Page, A. L. (1982). Methods of Soil Analysis. Part 2: chemical and microbial properties $\left(2^{\text {nd }}\right.$ Ed.)Am.Soc.Agron.in SoilSci.Soc. Am.Inc .Madison. Wisconsin, USA.

Rangarajan, A.; W. Brinton; A. Gabrial; L. Tivers and B. Calowell (2000). Organic Farming Research Foundation Project Report, Sarta Cruz, California, USA.

Rechcing,J.E. (1995). Soil Amendments and Environmental Quality, CRC. Press, Inc.

Saleh, A.L.;A.Abd-Elfattah and A.S.Taalab(2003).yield response and nutrient uptake of cowpea following application of different organic compost mixture .Egypt.J.Soil Sci.43(4):567-576.

Snedecor,G.W. and W.G. Cochran(1980). Statistical Methods $.7^{\text {th }}$ Ed.225-330 .Lowa state Univ.,Press.,Ames, Lowa. USA

Sui,Y.and M. L. Thompson (2000). Phosphorus sorption, desorption, and buffering capacity in abio-solds- amended Mohsol. Soil Sci. Soc.Am.J.64:945-954.

Talha, N. I. (2003). Potential effects of bio-remedial management of some biosolids wastes on quality of soil and some field crops. (Ph.D.) Thesis, Fac. of Agric., Kafr EL-Sheikh.Tanta Univ. Egypt. 
Talha, N. I. Hamida M.A. EL-Sanafawy and Asmaa A.EL Basuny (2007). Utilization of rice straw and twon refuse composts for improving soil properties under wheat and corn crop rotation .J.Agric.Res.Kafer ELSheikh Univ., 33(4)947-698.

Tan,K.H.(Ed.)(1993). "Principles of Soil Chemistry" $2^{\text {nd }}$ Marcel Dekker Inc.,New York., USA.

$$
\begin{aligned}
& \text { تـاثير الكبريت وكمبوست قش الأرز على خواص الأرض ومحصول فول الصويا }
\end{aligned}
$$

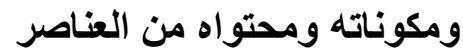

$$
\begin{aligned}
& \text { ناصر إبراهيم علي طلحة ، وابراهي العناهيم السيد اسماعيل نصر الدين ،بهجت عبد القوى زامل و }
\end{aligned}
$$

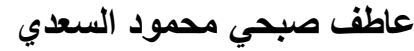

$$
\begin{aligned}
& \text { معهد بحوث الآراضي والمياه والبيئهـ مركز البحوث الزراعية } \\
& \text { أقيمت تجربة حقلية فى المزرعة البحثية بمحطة البحوث الزر اعية بسخا- محافظة كفر الثيخ سمصر }
\end{aligned}
$$

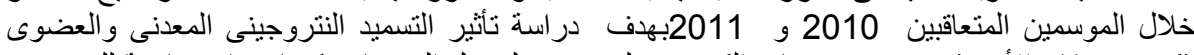

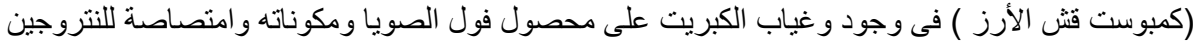

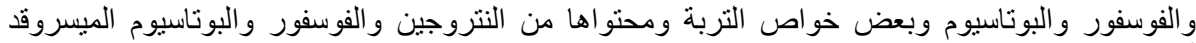

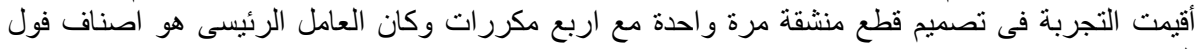

$$
\begin{aligned}
& \text { الصوياو هى النىر } \\
& \text { ( Crowford } \left.\left(\mathrm{Cv}_{1}\right)\right) \text { ( } 1 \\
& \text { ( Giza, 111(Cv } \\
& \text { (Taiwan } \left.\left(\mathrm{Cv}_{3}\right)\right) \text { ( }
\end{aligned}
$$

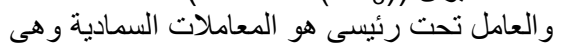

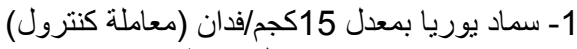

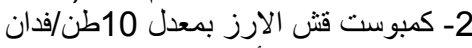

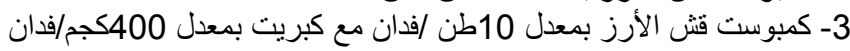

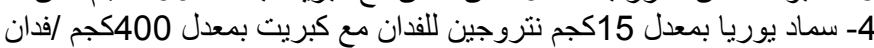

$$
\begin{aligned}
& \text { وتتلخص النتائج كمايلى :- } \\
& \text { 1- محصول فول الصويا ومكوناته تأثرت معنويا بكل من المعاملات السمادية المعدنية والكمبوست و أيضا }
\end{aligned}
$$

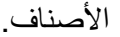

$$
\begin{aligned}
& \text { 2- أعلى قيمة للمحصول الحيوى ومحصول الحبوب كانت مع معاملة الكمبوست والكبريت مع صنف } \\
& \text { كراوفورد } \\
& \text { 3- أعلى محتوى للحبوب من النتروجين والفوسفور والبوتاسيوم مع معاملة الكمبوست مع صنف } \\
& \text { كراوفورد } \\
& \text { 4- أعلى محتوى للقش من النتروجين والفوسفور مع معاملة الكنترول بينما اعلى محتوى من البوتاسيوم مع } \\
& \text { معاملة الكمبوست مع الكبريت التريت }
\end{aligned}
$$

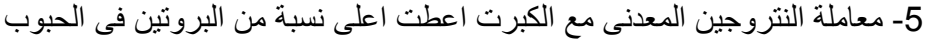

$$
\begin{aligned}
& \text { 6- معاملة الكمبوست حققت اعلى تركيز ميسر في التربة من من النتروجين البروتين فالفوسفور و البوتاسيوم وزيادة المادة } \\
& \text { العضوية وانخفاض التمبر التربة التركيز }
\end{aligned}
$$


Talha N. I. A. et al. 